\title{
PSYCHOLINGUISTIC MEANINGS OF PLAYFULNESS
}

\author{
Iia Gordienko-Mytrofanova \\ ikavgm@gmail.com \\ Iuliia Kobzieva \\ yu.kobzeva88@gmail.com \\ Serhii Sauta \\ sergeisauta@gmail.com
}

Hryhorii Skovoroda Kharkiv National Pedagogical University, Ukraine

\author{
Received May 26, 2019; Revised June 16, 2019; Accepted June 28, 2019
}

\begin{abstract}
The aim of the article is to describe psycholinguistic meanings of the word-stimulus "playfulness" in the linguistic world-image of the Russian-speaking population of Ukraine. The main method of the conducted research was the psycholinguistic experiment. The sample according to the criteria "gender" (males and females - included both age groups) and "age" (18-35 and 36-60) included 1,600 respondents with 400 people in each sub-group of respondents. The overall number of reactions to stimulus "playfulness" comprised 1,600 associative reactions with 475 unique associations including word combinations and sentences, where 159 reactions have frequency over 1,316 individual associations, and 0 refusals. The semantic interpretation of the results of the free association test made it possible to single out 19 psycholinguistic meanings, 12 out of them accounted for more than 1\%:1) "cheerful and joyful state", 2) "intention to attract the attention of the opposite or one's own sex", 3) "child-like spontaneity", 4) "agility, physical activity of an animal", 5) "daring and provocative behavior", 6) "agility, physical behavior of a human being", 7) "ease", 8) "changeability", 9) "behavior during a sexual intercourse", 10) "carelessness", 11) "mental activity", 12) "deliberate deceit". Taking into account the respondents' verbal behavior, the following components of playfulness were identified: flirting, impishness, humor, fugue (eccentricity), ease, imagination. The formulated psycholinguistic meanings of playfulness can be fully considered as such that give the most adequate and reliable model of the systemic significance of the studied word and which reflects the reality of linguistic consciousness.
\end{abstract}

Keywords: playfulness; psycholinguistic meaning; psycholinguistic experiment; free word association test; semantic interpretation.

\section{Гордіснко-Митрофанова Ія, Кобзсва Юлія, Саута Сергій. Психолінгвістичні значення грайливості.}

Анотація. Статтю присвячено опису психолінгвістичних значень стимулу «грайливість» у мовній картині світу російськомовного населення України. Основним методом проведеного дослідження був психолінгвістичний експеримент. Вибірку за критерієм "вік” (18-35 і 36-60) і “стать” (чоловіки та жінки, враховуючи обидві вікові групи) склали 1600 респондентів: по 400 осіб у кожній підгрупі респондентів. Загальна кількість реакцій на стимул “грайливість” склала відповідно 1600 реакцій-асоціацій: 475 унікальних асоціацій, включаючи словосполучення та речення, з них реакцій із частотою більше $1-159$, одиничних - 316, відмов - 0. За результатами психолінгвістичного експерименту описано 19 психолінгвістичних значень, із них 12 більше 1 \%: 1) “жваво-радісний стан”; 2) “прагнення привернути увагу представників протилежної або своєї статі”; 3) “безпосередність поведінки

\footnotetext{
(C) Gordienko-Mytrofanova, Iia; Kobzieva, Iuliia; Sauta, Serhii, 2019. This is an Open Access article distributed under the terms and conditions of the Creative Commons Attribution 4.0 International Licence (http://creativecommons.org/ licenses/by/4.0).

East European Journal of Psycholinguistics, 6(1), 19-31. https://doi.org/10.5281/zenodo.3371627
} 
дитини"; 4) "рухливість, рухова активність тварини”; 5) “зухвало смілива, запальна поведінка"; 6) “рухливість, рухова активність людини”; 7) “легкість”; 8) “мінливість”; 9) “поведінка під час сексу"; 10) “безтурботність”; 11) “розумова активність”; 12) “умисне введення в оману”. Психолінгвістичні значення дозволили, з огляду на вербальну поведінку респондентів, виявити такі компоненти грайливості: флірт, пустотливість, гумор, ф“юг (ексцентричність), легкість, уява. Сформульовані психолінгвістичні значення грайливості з упевненістю можна розглядати як такі, що дають найбільш адекватну й достовірну модель системного значення слова «грайливість», що відображають реальність мовної свідомості.

Ключові слова: грайливість; психолінгвістичне значення; психолінгвістичний експеримент; вільний асоціаціативний експеримент; семантична інтерпретація.

"... the associative field of a stimulus word is not only a fragment of the verbal memory of a human being, but also a fragment of the image of the world shared by a particular ethnos, reflected in the consciousness of an average representative of the culture, his/her motives and judgments, and, consequently, cultural stereotypes"

(Ufimtseva, 2009, p. 98).

\section{Introduction}

During the last twenty years, one can observe a radical reorientation from fragmentary mentions of playfulness in psychological texts (Bowman, 1987; Bundy, 1996; Chandler, 1997) to the establishment of the latter as a stable personality trait in theoretical psychological studies (Guitard et al., 2005; Barnett, 2007; Shen, 2010; Yarnal \& Qian, 2011; Proyer, 2012; Yue et al., 2016; Gordienko-Mytrofanova \& Sauta, 2016; Gordienko-Mytrofanova \& Kobzieva, 2017).

In Ukraine, we are the pioneers in the field of study of playfulness as a sustainable personality trait, and we study it in the perspective of the psycholinguistic approach, since "the reality of each concept manifests itself in the language" (Kondakov, 1975, p. 457). The essence of playfulness is realized through the psycho-linguistic experiment which is carried out through the reconstruction of its essential characteristics as semantic components, actualized in the consciousness of native speakers. The psycho-linguistic experiment aims to describe the psycholinguistic meanings of playfulness.

Psycholinguistic meaning is the psychologically real meaning of a word. It bears a tremendous cognitive value in studying of phenomena, expressed by words with unclear semantics. It allows us to establish of the actual definitions and semantic components, which are different from the lexicographic correlate and the communicative meaning of the word in question and are useful for the description of scientific phenomena (Sternin \& Rudakova, 2011).

The concept of a psycho-linguistic meaning as the most adequate and reliable model of systemic meaning is being actively developed by I. Sternin and his school (Rudakova, A. V., Maklakova, Ye. A., Friedman, J. I. et al.). The authors of the concept of the psycho-linguistic meaning have developed a template model for the identification and description of the psycholinguistic meaning and the variants for 
formulating the meaning based on the results of the psycholinguistic experiments with varying degree of detail determined by different goals (Rudakova, 2015).

The experience of specialists in this field has convincingly shown that the freeassociative experiment is the most effective tool for describing psycho-linguistic meanings. The results of associative experiments are subjected to the semic interpretation procedure, i.e. associative reactions are interpreted as the verbalization of particular semes of the stimulus-word.

It should be noted that from the point of view of the psycho-linguistic approach, playfulness is the subject of research performed by R. Proyer. In terms of psycho-linguistic tools, the analysis of the linguistic corpus of the German language and the Goldberg hierarchical approach to studying the structure of playfulness was applied. The analysis revealed the following seven factors: 1) cheerful-engaged; 2) whimsical; 3) impulsive; 4) intellectual-charming; 5) imaginative; 6) lighthearted; 7) kind-loving (Proyer, 2012).

In his other research work R. Proyer outlined five factors, such as: cheerfulengaged; whimsical; creative-loving; intellectual; impulsive. He discovered that the sense of humor was most strongly related with the cheerful-engaged factor while some "humor skills" were particularly related to other factors; for example, finding humor under stress with the intellectual component (Proyer, 2014).

The purpose of this article is to describe psycholinguistic meanings of playfulness on the basis of the applied psycholinguistic research, which is expected to let us come closer to the description of its systemic meaning.

The primary objectives are the following: to reveal the semantic components of playfulness, actualized in consciousness of native speakers in the unity of all the semantic components that make it up, both core and peripheral; to present the most cost-effective experimental procedures in order to group associates in the process of describing psycholinguistic meanings; to show the psycholinguistic meaning as a type of meaning which bears a great cognitive value in studying phenomena expressed by words of unclear semantics, which are nonetheless relevant lexemes in the linguistic consciousness of native speakers.

\section{Methods}

Experiment was the main method of the conducted research, and the psycholinguistic experiment in particular, which was aimed at the description of the psycholinguistic meaning of the word "playfulness" as the most adequate and reliable model of systemic significance that reflects the reality of linguistic consciousness (Sternin \& Rudakova, 2011, p. 188). The main stage of the research was the free association test (with the word-stimulus "playfulness").

As additional methods of exploring playfulness, the following methods have been used: theoretical analysis of the relevant literary sources, a survey (aimed at refining the results of the free association experiment); questionnaires for further precision of the characteristics of the sample. As for mathematical and statistical analysis of the results of the research, frequency and cluster analysis have been 
applied, which helped to outline tendencies in the distribution of associations produced by the experimental group.

The free association experiment with the stimulus word "PLAYFULNESS" was conducted in the written form. According to the instruction, the respondents were supposed to indicate their gender, age, education/degree, profession/job position, marital status, and then write the first five words that come to their mind and are associated with the word "playfulness".

\section{The study}

The procedure of forming a sample in each association experiment has its own internal logic. Therefore, it is worth saying a couple of words about our sample, or samples to be more precise.

In one of our recent publications it was experimentally proved that the sufficient quantitative composition of the experimental sample ranges between 400 and 1500 people and depends on the quantitative and qualitative composition of the general population and the peculiarities of research (Gordienko-Mytrofanova et al., 2018). This means the sample should be large enough to reflect the major tendencies and features of the general population, and also meet the goal of the research.

It should be also mentioned that in our research general population encompasses the inhabitants of Ukraine (aged 18 to 75), whose linguistic consciousness is characterized by knowledge (including understanding) of the Russian language. According to the hypothesis of the study, further analysis of the results was foreseen for such indicators as age, gender, profession. This led to the division of the main general population into smaller groups according to key criteria.

Taking into account major social criteria and the fact that smaller general populations (strata) were to be singled out in the course of the analysis, the selection of respondents in the sample was made both quantitatively and qualitatively. The main strategy of selection is random selection (randomization), stratification with quantitative balancing (Gordienko-Mytrofanova et al., 2018).

Sample 1 reflected the characteristics of the main general population. The purpose - outlining general trends in associations. At the initial stage of the study, all 24 oblasts of Ukraine were covered, as well as all types of settlements, together with 40 cities. It was this available part of the main general population that constituted the sample for representation. The sample comprised 2,902 respondents.

Sample 2. The purpose - defining the influence of the profession on the nature and composition of associations. Within the strata of youth (group aged 18-35), which is a period when a person tries to find his or her self, we singled out clusters united by professional background. The sample comprised 500 people: 100 people representing each "type of occupation", males and females being equally represented.

Sample 3. The purpose - defining the influence of gender and age on the nature and composition of associations. Stratification of the general population was carried out, which caused the sample to become multistage. The sample according to the criteria "gender" (males and females - included both age groups) and "age" 
(18-35 and 36-60) included 1,600 respondents with 400 people in each sub-group of respondents. Within the framework of our research, we reduced the sample size from the point of view that the response rates in the samples of 1,600 and 3,000 respondents do not statistically differ judging from the obtained experimental data.

Our research was carried out during 2014-2017 and included a sequence of successive stages.

The influence of age, gender, and profession-related differences on the verbal behavior of respondents, as well as the scope and nature of associates produced by the stimulus word "playfulness" were thoroughly described in our works (Gordienko-Mytrofanova \& Sypko, 2015; Gordienko-Mytrofanova \& Sauta, 2016).

The semantic interpretation of the results was made on the basis of the linguistic material from Sample 2. According to the requirements of this procedure, the description of the psycho-linguistic meaning was conducted on the basis of the first reaction. The overall number of reactions to stimulus "playfulness" comprised 1,600 associative reactions with 475 unique associations including word combinations and sentences, where 159 reactions have frequency over 1,316 individual associations, and 0 refusals.

Having processed the results of the experiment, we built the associative field of the word-stimulus "playfulness".

Before talking about the results of the free association experiment, it is necessary to describe the stages of the research that preceded the psycholinguistic experiment.

Theoretical analysis. The analysis of theoretical and empirical works devoted to playfulness as a personality trait (Barnett, 2007; Guitard et al., 2005; Proyer, 2012; Yarnal \& Qian, 2011; Yue et al., 2016), as well as the analysis of playfulness scales from the available questionnaires: Adult Playfulness Scale, Five-Factor Personality Questionnaire, Playfulness Scale for Adults, Playfulness Scale for Young Adults, Older Adult Playfulness Scale, Adult Playfulness Trait Scale, Otherdirected, Lighthearted, Intellectual, and Whimsical playfulness (Glynn \& Webster, 1992; Tsuji et al., 1996; Schaefer \& Greenberg, 1997; Barnett, 2007; Yarnal \& Qian, 2011; Shen et al., 2014; Proyer, 2017) allowed us to outline 24 components of playfulness: cheerful-engaged; comedic; creative/ creative-loving; curiosity; dynamic; expressive; fugue; fun/ fun-loving/ fun seeking motivation; gregarious; humorous/sense of humor; imaginative/ fantasy; impish; impulsive; informal; intellectual; lighthearted; other-directed; sensitivity to internal experience; sentiment; silly/ enjoys silliness; spontaneous; uninhibited; upbeat; whimsical.

Lexicography. The preliminary stage of the psycholinguistic experiment also involved the lexicographic description of the adjective "playful" on the basis of the method of summarizing dictionary definitions, which was developed by I.A. Sternin and A.V. Rudakova (Sternin \& Rudakova, 2011, p. 21-29). We have analyzed as many as 20 dictionaries starting from XVIII century and established differences between modern and obsolete meanings of the word within its semantic structure. This enabled us to outline 14 meanings of the adjective "playful" which are represented by 14 synonymic rows respectively that encompass 54 synonyms of the 
word "playful: (1) sharp-witted, zippy, skittish, irrepressible, lively, passionate, frisky, quick; (2) fast, easy, movable; (3) ingenious, fanciful, bizarre, varied; (4) changeable, unstable; (5) light-hearted, carefree, cheerful, thoughtless, sprightly ...; (6) naughty, gamesome, funny, mischievous, waggish, frolicsome; (7) laid-back, easy, joking; (8) flirtatious, sexy; (9) frivolous, loose, equivocal, suggestive, flippant, indecent, sexy, provocative, scabrous, frivolous ...; (10) cheerful, fun, blithe, merry; (11) rebellious, audacious, risky; (12) exciting, thrilling; (13) fresh, vivid, bright; (14) arch, cunning (Gordienko-Mytrofanova, 2014a; 2014b; 2014c).

The outlined meanings were supposed to be used later to facilitate the subsequent grouping of associated word-reactions that were received in the course of free association experiment with the word-stimulus "playfulness".

Free association experiment. After lexicography we proceeded to the main stage of the psycholinguistic experiment, i.e. free association experiment with the word-stimulus "playfulness".

As it was mentioned above, having processed the results of the experiment, we proceeded to building the associative field of the stimulus word "playfulness".

The analysis of the scope and nature of associations convincingly proved that in terms of functioning 'playfulness' is a relevant lexeme in the linguistic consciousness of Ukrainian population, although there is no such notion as an aggregate of distinctive traits in the psychological discourse.

Also, it is worth mentioning that respondents generally adopt a positive attitude to the stimulus "playfulness". There are only 73 reactions (48 words) that represent negative attitude, which is $4.6 \%$ of the overall number of reactions $(1,600$ reactions).

Having analyzed the associative field, we proceeded to the semantic interpretation of the results of the experiment, which consists of the following subsequent operations: sememic attribution of associative reactions and semic interpretation of associative reactions (Sternin \& Rudakova, 2011, p. 141-145).

Semantic interpretation of reactions. On the stage of sememic attribution all associative reactions were arranged in groups according to their meanings from the point of view of denotation. In the course of our research we came to the conclusion that it is not worth using the results of lexicography when arranging reactions in groups. To process such a large number of reactions, a new tool was created that filters meanings with the help of statistical functions in Excel program. The filter of meanings was created on the basis of 2,500 reactions and was described in our article "Playfulness as a peculiar expression of sexual relationships (semantic interpretation of the results of the psycholinguistic experiment)" (GordienkoMytrofanova \& Sauta, 2016).

Having divided 1,600 reactions into clusters with the help of filters, we proceeded to semic interpretation. On the stage of semic interpretation the produced reactions were interpreted as linguistic representations of the stimulus (semes). Associates that are close in meaning were grouped together, and their frequency was summed up, e.g.: Jesting 24 [jesting 22 [jesting 14, jokes 4, joke 3, joker 1; anecdotes 1 ; swearing playfully while driving 1$]$. 
The formulated semes of the outlined meanings were arranged in a connected definition of the meaning. The definitions were formulated as an organized connected enumeration of experimentally outlined semantic components of each of the interconnected meanings. Each meaning was formulated separately.

\section{Results and Discussion}

Psycholinguistic meanings. All the meanings given below were described in consultation with professor I. A. Sternin, the author of the concept of the psycholinguistic meaning (Gordienko-Mytrofanova \& Sauta, 2016).

Playfulness (1,600 respondents)

\section{CHEERFUL AND JOYFUL STATE}

Caused by MERRY-MAKING 147, JOY 59; can be caused by drinking CHAMPAIGN 35 or other ALCOHOL 12; as well as VICTORY 1, SUCCESSFUL DAY 1; is connected with ENTERTAINMENTS 8 - MUSIC 5, DANCES 3, SONGS 1; SATISFACTION 5; in terms of behavior reflects itself in MISCHIEVOUSNESS 48, FROLICKING 5, JESTING 24 , FRISKNESS 23, HORSEPLAY 19, PECULIARITIES of behaviour 7; FERVOUR 8; DRIVE 1; is accompanied by GOOD MOOD 37; OPTIMISM 1, POSITIVENESS 1; feeling of EASE 23, CHEERFULNESS 6, VIVACITY 5, FREEDOM 3, VIGOUR 2, ELATION 1; expressing EMOTIONS 8; feeling HAPPINESS 10; DELIGHT 3; is expressed in LAUGHTER 33; is a characteristic feature of a HOLIDAY 14 with PAPER STREAMERS 1, FIREWORK 1, SALUTE 1, CLOWN 1 in a CLUB 1, CABARET 1, CIRCUS 1; assumes a COMPANY 1.

\section{Cumulative Index of Brightness (CIB) ${ }^{1}-574(35.9 \%)$.}

\section{INTENTION TO ATTRACT THE ATTENTION OF THE OPPOSITE OR ONE'S OWN SEX}

Reflects itself as FLIRTING 66, COQUETRY 45; is characteristic of YOUNG GIRLS 24, WOMEN 15, SMALL GIRLS 3, COQUETTE 2, BLONDE 2, BEAUTY 2, CUTIE 2, GOLD-DIGGER 1; with CURL 1, wearing a SKIRT 1, STICKINGS 1, LACE 1 and with a BRACELET 1; is characteristic of a MAN 1 - BLOKE 1, BEDHOPPER 1, PLAYBOY 1; BOY 1;

reflects itself in BEHAVIOUR 2 as MISCHIEVOUSNESS 49, FROLICKING 5, JESTING 23, DALLIANCE 16, LIGHT-MINDEDNESS 15, LACK OF SERIOUSNESS , CUNNING 9, DUBIOUSNESS 2; SOCIABILITY 4, WITTINESS IN A CONVERSATION 1; DRIVE 1, SELF-INDULGENCE 1; in the STYLE OF CLOTHING 2; in a SMILE 15, in a GLANCE 5, MOVEMENT 3, GAIT 2, TONE 2; sometimes in ACTING UP 1, PRIMNESS 1, GRIMACES 1; expresses itself in the demonstration of SEXUALITY 11, ATTRACTIVENESS 5, PIQUANCY 4, CHARM 4, BEAUTY 3, FEMININITY 2, MYSTERIOUSNESS 2, COYNESS 2, ZEST 1, IMPRESSIVENESS 1, GALLANTRY 1, CHARM 1, EXQUISITENESS 1; using HINTS 3; is caused by LOVE 10, INFATUATION 5, PASSION 5, TEMPTATION 4, FEELINGS 2, INTRIGUE 2, INTEREST 2, ATTENTION,

\footnotetext{
${ }^{1}$ Cumulative Index of Brightness (CIB) is the cumulative frequency of reactions that actualize a particular meaning.
} 
AFFECTION 1, feeling of TENDER ADORATION 1; is demonstrated in personal RELATIONSHIPS 6 in the atmosphere of INTIMACY 5 and ROMANTICISM 4 during DATES 4 IN THE EVENING 1, for example, in a CLUB 2 or in a CABARET 1, during DANCES 3; on a BEACH 1; in a COMPANY 1.

CIB - 455 (28.44 \%).

\section{CHILD-LIKE SPONTANEITY}

Is characteristic of a CHILD 54; and predetermined by CHILDHOOD 32; reflects itself in the peculiarities of their CHARACTER 2 or TEMPER 1; manifests itself in behaviour as MISCHIEVOUSNESS 49, FROLICKING 5, HORSE PLAY 18, FRISKINESS 25, ACTIVITY 20, RESTLESSNESS 11, AGILITY 8, BRISKNESS 8, LIVELINESS 2, SHREWISHNESS 1; in love for TICKLING 1; manifests itself in such features as NAIVETY 4, SPONTANEITY 3, AMIABILITY 2, TRUST 1, OPENNESS 1, TRUTHFULNESS 1; can be displayed in CIRCUS 4 with a CLOWN 1, at the CHILDREN'S PARTY 4; when playing with a BALL 5, TOUCH GAME 1, A GAME OF TAG 1; on the SWING 1; when playing with LETTERS 1, TOY BLOCKS 1, SOAP BUBBLES 1, BABY RATTLES 1; when watching CARTOONS 1; in love for SWEET THINGS 1; can also reflect itself in AGE 1 YOUNG AGE 9 and YOUTH 2. dare 1);

precedent texts 1 - "Love Me If You Dare", French melodrama (love me if you

$$
\text { CIB - } 285 \text { (17.81\%). }
$$

\section{AGILITY, PHYSICAL ACTIVITY (OF AN ANIMAL)}

Is characteristic of ANIMALS 9, KITTEN 79, DOG 23, HORSE 11, RABBIT 1, as well as of wild animals, BEASTIES 2, that can be seen in the ZOO 1, - BABY TIGER 3, BABY LION 1, MARMOSET 1, CHIMPANZEE 1, YOUNG SQUIRREL 1, BUNNY 1; HIPPO 1, OTTER 1; of BEETLES 1; is also connected with the characteristic features of animals, such as - MANE 2, TAIL 2, FLUFFY FUR 1.

\section{CIB - $143(8.94 \%)$.}

\section{DARING AND PROVOCATIVE BEHAVIOR}

Can be caused by drinking CHAMPAIGN 35 or other ALCOHOL; playing ROULETTE 1; is connected with CRIME 2, RISK 1, EXTREME ACTIVITIES 2, DRIVING 1 a CAR 1; reflects itself in GUSTO 22, FERVOUR 8, BOLDNESS 8, FLIGHTINESS 5, FURY 2, DARE-DEVILRY 2, DRIVE 1, SPONTANEITY 1, SHREWISHNESS 1; is accompanied by EXCITED SPEECH 3, AGITATION 1, ADRENALINE 1 rush.

precedent texts 2 - thriller movie "Bullies", (Bullies 1); movie "Thief"; (Thief 1).

CIB - 112 (7\%).

\section{AGILITY, PHYSICAL ACTIVITY (OF A HUMAN)}

Manifests itself as FRISKINESS 25, ACTIVITY 20, AGILITY 8, BRISKNESS 8, LIVELINESS 2, HASTINESS 2; in SPORT 5 - FOOTBALL 6, BOXING 2, BADMINTON 1, BASKETBALL 1; in games with a BALL 5, TOUCH GAME 1, A GAME OF TAG 1; during WORK OUT 1; when RIDING 1 a BICYCLE1.

CIB - 90 (5.63\%).

\section{EASE}


EASE 23 is accompanied by the feeling of CHEERFULNESS 6, VIVACITY 5, FREEDOM 3, VIGOUR 2, ELATION 1; but can also be experienced as the STATE of 1 CARELESSNESS 10 , BEING RELAXED 3, SAFETY 1.

\section{CIB - $55(3.4 \%)$.}

\section{CHANGEABILITY}

Is characteristic of phenomena of NATURE 1 that are connected with WATER 1 , - STREAM 2, WATERFALL 1, WAVES 1, STEAM 1; various light phenomena, such as RAINBOW 2, SUNBEAMS 1, in the effects of ILLUMINATION 1 - GLITTER 1, SPARKLING 1, absence of light stream/reflection - BLACK 1, nature of light WAVE-CORPUSCLE DUALISM 1; sources of LIGHT 1 - SUN 3, FIRE 2; as well as WIND 3 [wind 2, mild breeze 1]; seasons - SPRING 3, SUMMER 2; WEATHER 1 conditions; BUBBLES OF CHAMPAIGN 1; can be perceived in material objects, such as BEADS 1, A PLANK OF WOOD 1, WIRE 1, TABLE 1, TRACTOR 1, STEEL SHAVINGS 1 and some processes that are connected with them - WELDING 1, SETTING UP A LATHE 1, SORTING OUT THE TILES 1; also characteristic of PAIN 1, SALARY 1, HEALTH 1, WORK 1, EXAM 1.

\section{CIB - 45 (2.81\%).}

\section{BEHAVIOR DURING SEXUAL INTERCOURSE}

Assumes FOREPLAY 2 before SEX 16, including elements of ROLE GAMES 2, KISSES 1, STRIPTEASE 1, TICKLING 1; TENDERNESS 4, CARESSING 3 with the aim of getting SATISFACTION 4; can end up in PREGNANCY 1.

\section{CIB - 35 (2.19 \%).}

\section{CARELESSNESS}

CARELESSNESS, is characteristic in the period of RELAXATION 6, IDLENESS 1 in front of TV SET 1, with FAMILY 1, on the EXCURSION 1; is experienced as the STATE 1 BEING RELAXED 3, SAFETY 1.

\section{CIB - 25 (1.56 \%).}

\section{MENTAL ACTIVITY}

Manifests itself in INTEREST 4, IMAGINATION 3, CREATIVITY 2, RESOURCEFULNESS 2, CURIOSITY 2, JOYFUL SOPHISTICATION 2, caused by something EXCITING 4, ABILITY TO ORGANIZE A GAME 1; enables the process of DEVELOPMENT 3, SELF-REALIZATION 2 its final manifestation is WISDOM 3.

precedent texts 1- "Discovery", documentary television channel (Discovery 1);

\section{CIB - 25 (1.56 \%).}

\section{DELIBERATE DECEIT}

Manifests itself in CUNNING 9, DUBIOUSNESS 2, DECEIT 2, RUSE 1; as ACTING 1, DUPLICITY 1, MASK 1; GRUMBLING 1; can take place during BARGAINING 1, EXCHANGE 1; its example can be EXHIBITORY DEMOCRATISM 1.

$$
\text { CIB - } 21 \text { (1.31\%). }
$$




\section{UNIQUE DISTINCTNESS}

Manifests itself as UNIQUENES 6 of a PERSON 2 and their LIFE 3, as well as the inner structure of, for example, a CHRISTAL 1, which causes SURPRISE 1.

CIB - 13 (0.81\%).

\section{AN ADULT CHANGING THEIR BEHAVIOR TO MATCH THAT OF A CHILD}

Manifests itself as STUPIDITY 3 and INFANTILISM 2.

precedent texts 1 -Marya Ivanovna, a character of jokes, archetype of an average stupid woman (Maks Frai) (Marya Ivanovna 1).

CIB - $6(0.38 \%)$.

\section{AIMLESS MOVING OF AN OBJECT}

to play with a PEN 1, WATCH 1 .

CIB - $2(0.13 \%)$.

\section{AIRINESS}

its examples are AIRINESS 1 of a LIGHT BREEZE 1.

CIB - $2(0.13 \%)$.

17. GAME (false meaning)

game 60 , games 8 , to play 7 , toys 2 , to play with toys 1 .

CIB - 78 (4.88 \%).

\section{PLAYING GAMES (false meaning)}

To play with a BALL 5, FOOTBALL 4, BADMINTON 1, BASKETBALL 1, TOUCH GAME 1, A GAME OF TAG 1, playing on COMPUTER 3, SLOT MACHINES 1, CARDS 1, CHECKERS 1, playing the GUITAR 1.

\section{CIB - $20(1.25 \%)$.}

\section{GAME ADDICTION (false meaning)}

Can be connected with ADDICTION 2 to COMPUTER 3, SLOT MACHINES 1, CARDS 1, ROULETTE 1, that borders on HYPERCOMPENSATION 1.

precedent texts 1 - "Igromania" magazine, monthly Russian multiplatform magazine about videogames (Igromania 1)

\section{CIB - $10(0.63 \%)$.}

11 associative reactions defy interpretation: phonetic reactions (7 reactions), they are phonetic in the Russian language: PLAYFULNESS - sleepiness 3, cuteness 2 , pediculation 1, sweatiness 1; echo-reactions (3 reactions): PLAYFULNESS - playfulness 3; individual reactions, where the connection is of particular individual nature and cannot be understood by the researcher; it is impossible to single out some meaningful connections with the stimulus (1 reaction): PLAYFULNESS - act 1.

It is also worth noting that all the lexicographic meanings of the adjective "playful" that we described earlier (Gordienko-Mytrofanova, 2014a; 2014b; 2014c) are reflected in the psycho-linguistic meanings. Moreover, some new meanings have appeared which were not to be found in dictionaries before.

The psycholinguistic meanings that were described involve all playfulness scales revealed in the course of the theoretical analysis of playfulness questionnaires. 
The meaning filtering tool helped us to outline and describe the influence of gender, age, and occupation on the stimulus "playfulness". The results of the analysis will be described in further articles.

The analysis of these psycholinguistic meanings helped us to single out the following components of playfulness: flirting, impishness, humor, fugue (eccentricity) (Gordienko-Mytrofanova \& Kobzieva, 2018), ease, imagination.

\section{Conclusions}

The psycholinguistic experiment revealed 16 psycholinguistic meanings, excluding false ones, where 12 meanings accounted for more than 1\%: 1) "cheerful and joyful state", 2) "intention to attract the attention of the opposite or one's own sex", 3) "child-like spontaneity", 4) "agility, physical activity of an animal", 5) "daring and provocative behavior", 6) "agility, physical behavior of a human being", 7) "ease", 8) "changeability", 9) "behavior during a sexual intercourse", 10) "carelessness", 11) "mental activity", 12) "deliberate deceit".

The formulated psycholinguistic meanings of playfulness can be fully considered as such that give the most adequate and reliable model of the systemic significance of the studied word, which reflects the reality of linguistic consciousness. The conducted research has shown that the psycholinguistic meaning helps to identify the relevant semantic components of the studied word ("playfulness"), different from its lexicographic correlate, and also to distinguish between scientific and everyday meanings of the word.

An essential advantage of the psycholinguistic meaning is that major attention is paid to the real traits of verbal behavior in representatives of different age groups, genders and professions, instead of the language structure.

Taking into account the respondents' verbal behaviour, the following components of playfulness were identified: flirting, impishness, humor, fugue (eccentricity), ease, imagination.

As for the prospect of further research, it appears worthwhile to describe the components of playfulness as components of (ludic competence) and create a questionnaire on ludic competence.

\section{Acknowledgements}

The authors express deep gratitude and appreciation to Iosif Sternin, professor of Voronezh State University, for valuable advice and recommendations when mastering the method of describing psycho-linguistic meaning. The authors are also profoundly grateful to Heijiro Tsuji, Professor Emeritus of Konan Womens' University, Kobe, Japan, for providing all the necessary materials and genuine interest to our research; also to Rene Proyer, professor of the Martin Luther University, to Willibald Ruch, professor of the University of Zurich, and to Paulette Guitard, associate professor of the University of Ottawa for their valuable support in exploring playfulness. 


\section{References}

Barnett, L. A. (2007). The nature of playfulness in young adults. Personality and Individual Differences, 43, 949-958.

Bowman, J. R. (1987). Making work play. In: Meaningful play, playful meanings. (pp. 61-71). G.A. Fine (Ed.), Champaign, IL: Human Kinetics.

Bundy, A. C. (1996). Play and playfulness: what to look for. In: Play in Occupational Therapy for Children, (pp. 52-66). D. L. Parham \& L. S. Fazio (Eds.). St. Louis, MO: Mosby.

Chandler, B. E. (1997). The essence of play: a child's occupation. Bethesda, MD: American Occupational Therapy Association, Inc.

Glynn, M. A., Webster, J. (1992). The adult playfulness scale: An initial assessment. Psychological Reports, 71(1), 83-103.

Gordiienko-Mytrofanova, I. V. (2014a). Leksikograficheskoie znacheniie slova "igrivost" (podgotovitelnyi etap psikholingvisticheskogo eksperimenta) [The lexicographic meaning of the word "playfulness" (the preparatory stage of the psycholinguistic experiment)]. Psychological Prospects Journal, 24, 65-77.

Gordiienko-Mytrofanova, I. V. (2014b). Psikhologicheskoie soderzhaniie leksikograficheskikh znachenii slova "igrivyi" (podgotovitelnyi etap psikholingvisticheskogo eksperimenta) [The psychological content of the lexicographic meanings of the word "playful" (the preparatory stage of the psycholinguistic experiment)]. Problemy suchasnoi pedahohichnoi osvity Problems of Modern Pedagogical Education, 45(2), 419-430.

Gordiienko-Mytrofanova, I. V. (2014c). Psikhologicheskaia interpretatsiia leksikograficheskogo opisaniia slova "igrivyi" [Psychological interpretation of the lexicographic description of the word "playful”]. Problemy Suchasnoi Psykholohii-Problems of Modern Psychology, 25, 8398.

Gordienko-Mytrofanova, I., Sypko, A. (2015). Playfulness as a relevant lexeme in the bilingual linguistic consciousness of Ukrainian people. East European Journal of Psycholinguistics, 2(1), 43-51.

Gordienko-Mytrofanova, I., Sauta, S. (2016). Playfulness as a peculiar expression of sexual relationships (semantic interpretation of the results of the psycholinguistic experiment). European Humanities Studies: State and Society, 1, 46-62.

Gordienko-Mytrofanova, I., Kobzieva, I. (2017). Humor as a component of ludic competence. Visnyk [Journal] of the Hryhorii Skovoroda Kharkiv National Pedagogical University, 57, 4056.

Gordienko-Mytrofanova, I., Kobzieva, I. (2018). Concept «Holy Fool» in the Linguistic WorldImage of the Russian-Speaking Population of Ukraine. Psycholinguistics, 24(1), 118-133.

Gordiienko-Mytrofanova, I., Pidchasov, Y., Sauta, S. Kobzieva, I. (2018). The problem of sample representativeness for conducting experimental and broad psychological research. Psycholinguistics, 23(1), 11-46.

Guitard, P., Ferland, F., \& Dutil, É. (2005). Toward a better understanding of playfulness in adults. OTJR: Occupation, Participation and Health, 25(1), 9-22.

Kondakov, N. I. (1975). The Logical Dictionary-Reference. Moscow: Nauka.

Proyer, R. T. (2012). A Psycho-linguistic Study on Adult Playfulness: Its Hierarchical Structure and Theoretical Considerations. Journal of Adult Development, 19(3), 141-149.

Proyer, R.T. (2014). A Psycho-Linguistic Approach For Studying Adult Playfulness: A Replication and Extension Toward Relations With Humor, The Journal of Psychology, 148(6), 717-735.

Proyer, R.T. (2017). A new structural model for the study of adult playfulness: Assessment and exploration of an understudied individual differences variable. Personality and Individual Differences, 108, 113-122. 
Rudakova, A. V. (2015). On the concept of an integrated lexicographic meaning of a word and the methodology of its description. Culture of Communication and Its Formation: Interuniversity Collection of Scientific Works, 31, 109-115.

Schaefer, C. \& Greenberg, R. (1997). Measurement of Playfulness: A Neglected Therapist Variable. International Journal of Play Therapy, 6(2), 21-31.

Shen, X. (2010). Adult playfulness as a personality trait: Its conceptualization, measurement, and relationship to psychological well-being. Doctoral dissertation. Retrieved from Pennsylvania State University Library Catalog (OCLC No. 859524715).

Sternin, I.A., \& Rudakova, A.V. (2011). Psikholingvisticheskoie znacheniie slova i yego opisaniie [Psycholinguistic meaning of the word and its description]. Voronezh: Lambert.

Tsuji, Hit., Tsuji, Hei., Yamada, S., Natsuno, Y., Morita, Y., Mukoyama, Y., Hata, K., Fujishima, Y. (1996). Standardization of the Five Factor Personality Questionnaire: Factor structure. International Journal of Psychology, 31. Proceedings from the XXVI International Congress of Psychology. August 16-21, 1996, Montreal, Canada. (103-217).

Ufimtseva, N. V. (2009). Obraz mira russkikh: sistemnost i soderzhaniie [Image of the world of Russians: the systemic characteristics and the content]. Yazyk i kultura - Language and Culture, 98-111.

Yarnal, C., \& Qian, X. (2011). Older-adult Playfulness: An innovative construct and measurement for healthy aging research. American Journal of Play, 4(1), 52-79.

Yue, X. D., Leung, C. L., Hiranandani, N. A. (2016). Adult Playfulness, Humor Styles, and Subjective Happiness. Psychological Reports, 119(3), 630-640. 